\title{
Performance of a stochastic-dynamic modelling methodology for running waters ecological assessment
}

\author{
Edna Cabecinha ${ }^{\mathrm{a}, *}$, Rui Cortes ${ }^{\mathrm{b}}$, João Alexandre Cabral ${ }^{\mathrm{a}}$ \\ ${ }^{a}$ Laboratory of Applied Ecology, CETAV-Department of Biological and Environmental Engineering, \\ University of Trás-os-Montes e Alto Douro, 5000-911 Vila Real, Portugal \\ ${ }^{\mathrm{b}}$ Department of Forestry Engineering, University of Trás-os-Montes e Alto Douro, 5000-911 Vila Real, Portugal \\ Received 28 January 2003; received in revised form 2 September 2003; accepted 27 October 2003
}

\section{Abstract}

An holistic stochastic-dynamic modelling methodology has been developed in order to predict the ecological status of lotic systems in Northeast Portugal. These procedures focus on the interactions between conceptually isolated key-components, such as some relevant benthic macroinvertebrate metrics and changes in local habitat conditions. The proposed model was preceded by a conventional multivariate statistical treatment performed to discriminate the significant relationships between prevailing biological and environmental variables. Since this statistical analysis is static, the dataset recorded from the field included true gradients of habitat changes. In this way, the factors time and space are implicit in the respective treatment. Such a procedure gives credibility to the parameters included in the dynamic model construction. In order to enhance the importance of monitoring in aquatic systems based on ecological integrity indicators, different biotic metrics were selected from the studied benthic macroinvertebrate communities. The samples of aquatic macroinvertebrate, environmental and physical-chemical data were collected from three watersheds of mountain rivers in Northeast Portugal, between 1983 and 1985. The model validation was based on independent data from another watershed not included in the model construction. Thereafter, the model behaviour was tested facing a "new" scenario, namely ongoing organic pollution disturbances in the region. The results are encouraging since, after the model validation, they seem to demonstrate the reliability of the model (1) to assess the ecological status of running waters from the studied watersheds and (2) to predict the behaviour of key macroinvertebrate metrics, along an ecological gradient from relatively pristine conditions to serious human impacts.

(C) 2003 Published by Elsevier B.V.

Keywords: Running waters; Aquatic ecosystem integrity; Ecological indicators; Aquatic macroinvertebrates; Stochastic-dynamic modelling; Holistic approaches

\section{Introduction}

The ability of humans to change the world outpaces the capacity of living systems to respond to those changes (Dolèdec et al., 1999; Kimberling et al.,

\footnotetext{
* Corresponding author. Tel.: +351-259-350-734; fax: $+351-259-350-480$

E-mail address: edna@utad.pt (E. Cabecinha).
}

2001). Therefore, most of the freshwater lotic ecosystems are subject to severe pressure by either an alteration in the quality or the quantity of the water, as well as the structure of these systems. This pressure forces changes in biotic communities, especially evidenced in a reduction of their characteristic biological diversity (Ribaudo et al., 2001; Harris, 2002). The progressive degradation of running waters takes place in most watersheds in Northeast Portugal (Cortes, 1992).

1 0304-3800/\$ - see front matter (C) 2003 Published by Elsevier B.V.

2 doi:10.1016/j.ecolmodel.2003.10.021 
For conservation and management purposes, the use of adequate ecological integrity indicators is particularly helpful in assessing the impact of environmental changes on characteristic ecological patterns (Barbour et al., 1999; Dolèdec et al., 1999; Rabeni, 2000; Andreasen et al., 2001; Dale and Beyeler, 2001; Karr and Rossano, 2001; Kurtz et al., 2001; Karr, 2002). Ecological integrity is a concept centered in the system as a whole, but depends on the state of all components, such as the presence of species, populations and autochthonous communities, the occurrence of appropriate ecological processes and the maintenance of all the environmental conditions that support the ecosystem (Angermeier and Karr, 1994; Townsend and Riley, 1999; Dale and Beyeler, 2001). Since ecological indicators can reflect biological, chemical and physical aspects of ecological conditions, they have been used to characterize status, to track or predict changes, to identify stressors or stressed systems, to assess risk and to influence management actions (Seager, 1999; Rabeni, 2000; Karr and Chu, 2001; Kurtz et al., 2001; Karr, 2002). The biological alterations due to extrinsic causes or inherent in the natural running of aquatic ecosystems can be considered at the molecular or physiologic level, at the individual level and at population or community levels (Cortes, 1992; Karr, 1998, 1999; Turak et al., 1999; Cortes et al., 2002). Key aquatic communities have been used, in some cases for decades, to evaluate the biological quality of streams, rivers and lakes (Karr, 2002).

In this paper, the macroinvertebrate communities were used as ecological integrity indicators of aquatic ecosystems. These communities have been commonly chosen for aquatic bioassessment investigations as aquatic invertebrates respond rapidly to environmental changes and provide signs for the early detection of ecological changes (Barbour et al., 1999; Kimberling et al., 2001). They are present in wide aquatic habitat types, possess life cycles with a relatively long aquatic phase giving information on short and long term disturbances and are relatively easy to sample and process due to their conspicuous nature (Wright et al., 1989, 1992; Hutchens et al., 1998; DeWalt et al., 1999; Whiles et al., 2000). Additionally, great progress has been made towards standardized methods of collection and analysis of these groups (Barbour et al., 1999; Karr and Rossano, 2001; Cortes et al., 2002). Other advantages of macroinvertebrate communities are related to the capacity for population recovery in response to good management procedures in previously disturbed ecosystems (Cortes, 1992; Barbour et al., 1999; Harris and Silveira, 1999; Karr, 2002). This recovery depends on countless factors such as the duration and nature of the disturbance, characteristics of the organisms (namely the life cycle phase) and the capacity of recolonization of affected habitats (Wallace, 1990; Yount and Niemi, 1990; Mackay, 1992; Hutchens et al., 1998; Rabeni, 2000; Kurtz et al., 2001). Therefore, several studies have demonstrated the effectiveness of invertebrate bioassessment for detection of stream reaches impaired by a variety of point and non-point source pollutants (see Lenat, 1998; Thorne and Williams, 1997; Karr, 1999, 2002; Maxted et al., 2000; Whiles et al., 2000; Kurtz et al., 2001).

One of the great challenges in ecological integrity studies is to predict how anthropogenic environmental changes will affect the abundance of species, guilds or communities in disturbed ecosystems (Andreasen et al., 2001). Although ecological models have been used to predict macroinvertebrate species responses to environmental stresses and habitat characteristics, most of them are static (e.g. Wright, 1995; Parsons and Norris, 1996; Kay et al., 1999; Marchant et al., 1999; Moss et al., 1999; Smith et al., 1999; Turak et al., 1999; Charvet et al., 2000; Oberdorf et al., 2001). Static models with fixed parameters are unable to estimate the structural changes when the habitat conditions are substantially changed (Jørgensen and Bernardi, 1997). Therefore, it is a goal of ecological modelling to construct dynamic models and structural dynamic models that can adequately capture the structure and the composition, including the related processes, of those systems (Jørgensen, 1994, 2001; Chaloupka, 2002). In fact, dynamic models are very important tools with which to improve the assessment of the medium- and long-term directional environmental disturbances in perturbed ecosystems (Jørgensen and Bernardi, 1997; Ault et al., 1999; Brosse et al., 2001; Cabral et al., 2001; Costanza and Voinov, 2001; Jørgensen, 2001; Voinov et al., 2001; Santos and Cabral, submitted). The application of dynamic ecological models can synthesize the pieces of ecological knowledge, emphasizing the need for an holistic view of a certain environmental problem (Mitsch and Jørgensen, 1989). 
The aim of the present paper is to develop an holistic, simple, expedite and applicable methodology, by using appropriate statistical and dynamic modelling techniques, in order to contribute to the assessment of the ecological status in running waters systems. A stochastic dynamic model was constructed and validated by focusing on the interactions between conceptually isolated key-components in such systems, namely between biological metrics and physicochemical conditions. These specific components of ecosystem integrity are intricately linked by their dependence on habitat characteristics, particularly their occurrence related to environmental conditions. Hypotheses to be tested include: (1) that the selected metrics are representative of the local macroinvertebrate community that changes in some predictable way with the increase of human influence; and (2) that the ecosystem integrity can be assessed by the state variables, assumed as important ecological indicators, used in the dynamic model construction. These hypotheses were tested by new applications of a stochastic dynamic model in order to capture, in an holistic perspective, the complex- ity of some ecological processes resulting from the 160 gradients of the ongoing environmental changes in the 161 studied watersheds of Northeast Portugal.

\section{Methods}

\subsection{Study area}

164

The study was carried out in four main streams from 165 the Douro river watershed, located in Northeast Por- 166 tugal: the Olo (O), Corgo (C), Pinhão $(\mathrm{P})$ and Tinhela 167 (T) rivers (Fig. 1). The watersheds of these rivers have 168 different lithological, topographical, hydrological and 169 land use features. The studied streams range from 2nd 170 to 10th in order of altitude $(50-1500 \mathrm{~m})$. The granite 171 and schist bedrocks create a common pattern of acid 172 and soft waters. Strongly seasonal irregular discharges, 173 related to the precipitation pattern and low retention 174 time are important characteristics. Land use reflects 175 the topographical conditions: the steep slopes are cov- 176 ered with rough pastures mixed with forests of pine

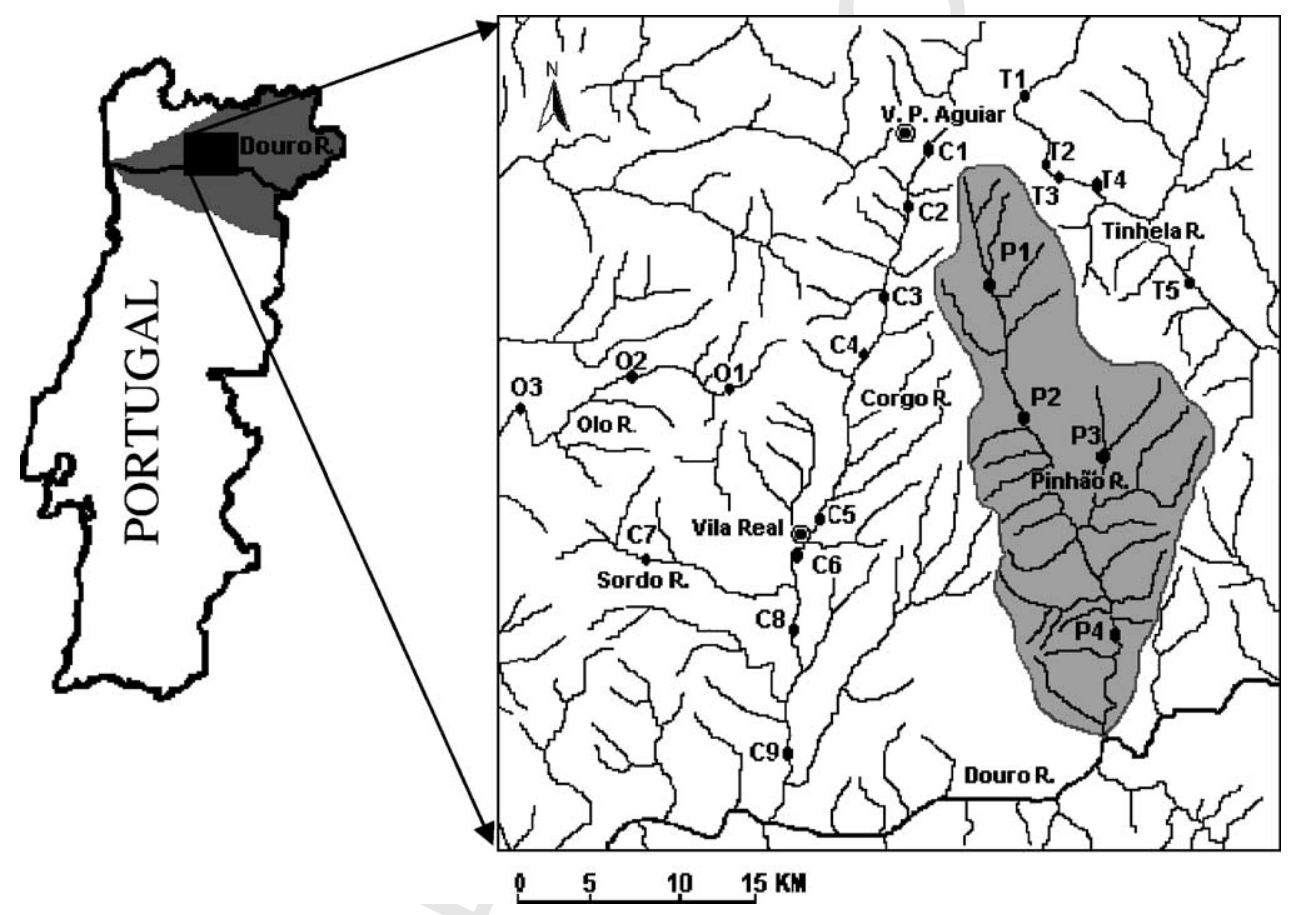

Fig. 1. Location of the study area in Northeast Portugal (shaded area) with the different watersheds used in the construction of the model (Olo (O), Corgo $(\mathrm{C})$ and Tinhela $(\mathrm{T})$ rivers) and in the respective validation (Pinhão river $(\mathrm{P})$ ). 
trees; few arable crops, using a small amount of fertilizers and large areas of vineyards are present in the lower lands. During the sampling period (1983-1985) some sources of disturbance have changed these features: an input of As, $\mathrm{Zn}$ and sulphates, resulting from spoil heaps created by gold mines have affected the Tinhela river, and sewage from urban areas has caused eutrophic conditions in the Corgo river.

\subsection{Field programme}

The environmental and biological data used to support the model construction was collected in 15 sampling stations from three watersheds $(\mathrm{O}, \mathrm{C}$ and $\mathrm{T}$, Fig. 1) (Cortes, 1992), representative of the typological variations in the studied region. The model was validated with independent data from four sampling stations (P1, P2, P3 and P4) located in the Pinhão watershed (Fig. 1). Sampling was carried out from March 1983 to November 1985. Four sampling campaigns were made annually, corresponding to spring, summer, autumn and winter periods (see Cortes, 1992 for details). In each campaign, semi-quantitative biological samples were taken monthly in each sampling station. Therefore, the recorded data allowed to incorporate into the model the seasonality of the natural variations that occurred in these aquatic systems. Aquatic macroinvertebrates were identified at species level with the exception of Acari (presence/absence), Oligochaeta (Family) and Chironomidae (sub-Family), and grouped in relevant metrics. The data were analysed according to measures of taxa richness, composition and tolerance to environmental disturbance. These biomonitoring metrics were used to assess river health as they reveal high sensitivity to environmental stress (see, Cortes, 1992; Thorne and Williams, 1997; Barbour et al., 1999; Harris and Silveira, 1999; Karr, 1999, 2002; Maxted et al., 2000). The specifications of all physicochemical and biological variables considered in this study are presented in Table 1.

\subsection{Data analysis}

The stochastic dynamic model proposed is preceded by a conventional multivariate statistical procedure. A stepwise multiple regression analysis (Zar, 1996) was used to test relationships between the biological
Table 1

Specification (units and taxa resolution) of all physicochemical and biological variables considered in this study

\begin{tabular}{|c|c|c|}
\hline Variables & Specification & Code \\
\hline \multicolumn{3}{|l|}{ Environmental variables } \\
\hline Alkalinity & meq. $1^{-1}$ & ALK \\
\hline Altitude of the site & $\mathrm{m}$ & ALT \\
\hline Biochemical oxygen demand & $\mathrm{mg} \mathrm{O}_{2} \mathrm{1}^{-1}$ & $\mathrm{BOD}_{5}$ \\
\hline Chemical oxygen demand & $\mathrm{mg} \mathrm{O}_{2} 1^{-1}$ & COD \\
\hline Chlorides & meq. $1^{-1}$ & $\mathrm{CL}$ \\
\hline Conductivity at $20^{\circ} \mathrm{C}$ & $\mu \mathrm{mhos} \mathrm{cm}^{-1}$ & COND \\
\hline $\begin{array}{l}\text { Distance from the stream } \\
\text { source }\end{array}$ & $\mathrm{km}$ & DSOURCE \\
\hline Hardness & meq. $1^{-1}$ & HARD \\
\hline Nitrates-N & $\mathrm{mg} \mathrm{N}-\mathrm{NO}_{3} \mathrm{l}^{-1}$ & $\mathrm{NO}_{3}$ \\
\hline Oxygen content & $\mathrm{mg}^{-1}$ & $\mathrm{O}_{2}$ \\
\hline $\mathrm{pH}$ & $\mathrm{pH}$ units & $\mathrm{pH}$ \\
\hline Precipitation & $\mathrm{mm}$ & PREC \\
\hline Temperature & ${ }^{\circ} \mathrm{C}$ & TEMP \\
\hline \multicolumn{3}{|l|}{ Integrity metrics } \\
\hline \multicolumn{3}{|l|}{ Composition measures } \\
\hline $\begin{array}{l}\text { Number of Chironomidae } \\
\operatorname{taxa}\end{array}$ & $\begin{array}{l}\text { No. of } \\
\text { sub-families }\end{array}$ & CHIR \\
\hline $\begin{array}{l}\text { Number of Ephemeroptera } \\
\text { taxa }\end{array}$ & No. of species & $\mathrm{EPH}$ \\
\hline Number of Plecoptera taxa & No. of species & PLEC \\
\hline Number of Trichoptera taxa & No. of species & TRIC \\
\hline Number of EPT taxa & $\begin{array}{l}\text { EPH + PLEC } \\
+ \text { TRIC }\end{array}$ & EPT \\
\hline \multicolumn{3}{|l|}{ Richness measures } \\
\hline Total number of taxa & No. of species & TOT \\
\hline Shannon-Wiener index & & $\mathrm{H}^{\prime}$ \\
\hline Pielou's evenness & & $\mathrm{E}$ \\
\hline \multicolumn{3}{|l|}{ Tolerance measures } \\
\hline EPT/(EPT + Chironomidae) & & $\begin{array}{l}\text { EPT and } \\
\text { CHIR }\end{array}$ \\
\hline
\end{tabular}

metrics and the environmental variables. The depen- 221 dent variables correspond to the selected metrics ex- 222 pressed in number of species, with the exception of 223 Chironomidae in sub-families. The independent vari- 224 ables were the environmental parameters displayed in 225 Table 1. A step down procedure was used so that the 226 effect of each variable in the presence of all others 227 could be examined first, with the least significant vari- 228 able being removed at every step. The analysis stopped 229 when all the remaining variables had a significance 230 level $P<0.05$ (Zar, 1996). Although the lack of nor- 231 mal distribution of the dependent variables was not 232 solved by any transformation (Kolmogorov-Smirnov 233 test), the linearity and the homoscedasticity of the 234 
residuals were achieved by using logarithmic transformations $\left(X^{\prime}=\log _{10}[X+1]\right)$ in each side of the equation, i.e. on both dependent and independent variables (Zar, 1996). The lack of multicolinearity between independent variables was assured by the inspection of the respective tolerance values.

Since the previous statistical procedures are static, the initial data set included true gradients of environmental characteristics and man-induced disturbances. In this way, the factors of time and space were implicit in the respective treatment and the significant partial regression coefficients were assumed as relevant holistic ecological parameters in the dynamic model construction. This is the heart of the philosophy of the stochastic dynamic model developed. This model does not distinguish between different species within the selected metrics, but considers them as a whole in each corresponding state variable. Therefore, from an holistic perspective, the partial regression coefficients represent the global influence of the environmental variables selected and are of significant importance in several complex ecological processes not included explicitly in the model, but related to the state variables or metrics under consideration. All the modelling procedures were developed using STELLA 5.0 ${ }^{\circledR}$.

For validation purposes, independent biological and physicochemical data from the four sampling stations of the Pinhão watershed (P1, P2, P3 and P4) were used to confront the simulated values of a given metric, resulting from the introduction of the respective real physicochemical data into the model, with the real values of the same metric contemporaneous to those environmental parameters. A regression analysis (Model II) was performed to compare the observed real values of the selected ecological metrics with the expected values obtained by model simulations for the same periods. At the end of each analysis, the $95 \%$ confidence limits for the intercept and the slope of the regression line were determined which, together with the results of the respective analysis of variance (ANOVA), allowed us to assess the proximity of the simulations produced with the observed values (Sokal and Rohlf, 1995). When the results of the regression analysis were statistically significant, i.e. when the intercept of the regression line was not statistically different from 0 and the slope was not statistically different from 1 , the model simulations were considered validated (Sokal and Rohlf, 1995; Oberdorf et al., 2001).
In order to quantify assessment we must be able to 283 specify the ecological properties that are expected to 284 occur in the absence of human alteration (the pristine 285 condition) or are attainable if human impact ceases. 286 Since we had no knowledge about the biota that existed 287 at the studied sites prior to human alteration, we took 288 the environmental data reported in the eighties as a 289 reference situation. In fact, in that period the studied 290 watersheds presented, in general, good water quality 291 (clean waters, not polluted or little altered), according 292 to the BMWP' (Alba-Tercedor and Sánchez-Ortega, 293 1998) and IBB (Pauw and Vanhooren, 1983) indexes. 294

After the validation process, the model performance 295 was analysed facing scenarios of water quality degra- 296 dation resulting from organic pollution. Since the 297 sampling station C6, located in the Corgo watershed, 298 was monitored in 1994 for chemical water quality 299 (Sampaio, 1995), approximately 10 years later than 300 the data used for the model construction, this data was 301 used to represent water quality degradation in this site. 302 In fact, according to Sampaio (1995), this sampling 303 station displayed a typical diagnosis of eutrophication. 304 Two scenarios for C6 were considered to evaluate the 305 sensitivity of the developed model in discriminating 306 real perturbations: scenario 1 was assumed, for com- 307 parative purposes, as a reference condition (in spite 308 of already not being an unpolluted site) and charac- 309 terized by the environmental data from 1984 (Cortes, 310 1992), and scenario 2 was identified as a perturbed 311 condition regarding environmental data from 1994312 (Sampaio, 1995). Thereafter, a Mann-Whitney test 313 was performed to compare two different time series 314 from the two scenarios considered.

\section{Results}

\subsection{Effects of environmental factors in biological metrics}

A stepwise multiple regression analysis was used to 319 search for significant correlations between the mixed 320 biological metrics and the mixed environmental vari- 321 ables of the three watersheds used in the model con- 322 struction. Of the 13 environmental variables consid- 323 ered, 4 were excluded from the model $(P>0.05), 324$ namely chemical oxygen demand, phosphates-P, chlo- 325 rides, and dissolved oxygen content. The environmen- 326 
Table 2

The regression equations, degrees of freedom (d.f.), coefficient of determination $\left(R^{2}\right)$

\begin{tabular}{|c|c|c|c|}
\hline Equations & d.f. & $R^{2}$ & $F$ \\
\hline $\log \mathrm{CHIR}=0.066+0.278(\log \mathrm{COND})-0.890(\log \mathrm{HARD})$ & 69 & 0.181 & $4.169^{*}$ \\
\hline $\log \mathrm{EPH}=1.805+0.255(\log \mathrm{DSOURCE})-1.718(\log \mathrm{pH})-0.831\left(\log \mathrm{NO}_{3}\right)$ & 68 & 0.263 & $6.637^{* * *}$ \\
\hline $\log$ PLEC $=-1.385+0.145(\log$ PREC $)+0.457(\log$ ALT $)+0.256(\log$ DSOURCE $)$ & 68 & 0.504 & $19.333^{* * *}$ \\
\hline $\log \mathrm{TRIC}=-0.300+0.305\left(\log \mathrm{BOD}_{5}\right)+0.274(\log \mathrm{ALT})-0.822\left(\log \mathrm{NO}_{3}\right)$ & 68 & 0.253 & $6.238^{* * *}$ \\
\hline $\log \mathrm{TOT}=2.548+1.492(\log \mathrm{ALK})-1.576(\log \mathrm{pH})-0.961\left(\log \mathrm{NO}_{3}\right)$ & 68 & 0.206 & $4.462^{* *}$ \\
\hline $\log \mathrm{H}^{\prime}=0.512+0.624(\log \mathrm{ALK})-0.093(\log \mathrm{COND})$ & 68 & 0.081 & $3.022^{*}$ \\
\hline
\end{tabular}

$F$-values and their significance level $\left({ }^{*} P<0.05\right.$; $\left.{ }^{* *} P<0.01 ;{ }^{* * *} P<0.001\right)$ for all the variables combination selected as significant by stepwise multiple regression. The specification of all variable codes is expressed in Table 1 .

tal variables associated with a longitudinal gradient seemed to be the main influencing factors on metrics related to those macroinvertebrates more sensitive to organic pollution. In fact, the increase in the number of species of Ephemeroptera and Plecoptera was positively correlated with the distance from stream source (Table 2). Moreover, the number of species of Plecoptera and Trichoptera seemed to be positively influenced by an increase of altitude (Table 2). The increase of nitrate concentrations, an indicator of potential organic perturbation, seemed to negatively affect the total number of taxa, and the Ephemeroptera and Trichoptera compositions (Table 2). The remaining physicochemical significant influences are expressed in Table 2.

\subsection{Model conceptualization and equations}

The diagram of the model presented in Fig. 2 is based on the relationships detected in multiple regression analysis (Table 2) and on existing relevant regional data sets (Cortes, 1992). Therefore, the model includes the following six state variables: four metrics related to the composition measures of benthic community and two related to their richness measures (Fig. 2). Difference equations that describe the processes affecting the state variables are expressed in a logarithm of composition and richness of the respective biological metrics (Table 3, Difference equations). The initial values of all state variables, indicated in Table 3 (Process equations), were assumed to be zero, given the lack of knowledge of the initial situation in t0. Later, for simulations representation, the initial value was discarded, since only in t1 (first month of the simulation) was it possible to take into account the influences of the environmental variables, whose sea- sonal fluctuations were introduced into the model as 361 table functions (Table 3, Table functions). 362

The inflows affecting the ecological metrics state 363 variables, Chironomidae (Chir gains), Ephemeroptera 364 (Eph gains), Plecoptera (Plec gains), Trichoptera 365 (Tric gains), total number of taxa (Tot gains), and 366 Shannon-Wiener index ( $\mathrm{H}^{\prime}$ gains), were based on the 367 positive constants and all positive partial coefficients 368 of each metric resulting from the previous multiple 369 regression analysis (Fig. 2, Tables 2 and 3, Difference 370 and Process equations). However, all metrics were 371 affected by an outflow (Chir losses, Eph losses, Plec 372 losses, Tric losses, Tot losses, $\mathrm{H}^{\prime}$ losses) related to the 373 negative constants and partial regression coefficients 374 (Fig. 2, Tables 2 and 3, Difference and Process equa- 375 tions). Although the composition and richness output 376 for each metric in our stochastic dynamic model sim- 377 ulation is composed of a given value per time unit, 378 the respective state variable may result in a cumula- 379 tive behaviour over time in response to environmental 380 condition changes. Therefore, to prevent this from 381 happening, six outflow adjustments were incorporated 382 into the model (Chir adjust, Eph adjust, Plec adjust, 383 Tric adjust, Tot adjust, and $\mathrm{H}^{\prime}$ adjust). These outflow 384 adjustments aim to empty the ecological metric state 385 variables at each time step, by a "flushing cistern 386 mechanism", before beginning the next step with 387 new environmental influences (Fig. 2 and Table 3, 388 Difference and Process equations). For process com- 389 patibilities and a more realistic comprehension of 390 the model simulations, some conversions were intro- 391 duced, denominated as associated variables (Fig. 2392 and Table 3, associated variables). Regarding the 393 biological metrics, these conversions were obtained 394 through an inverse transformation (anti-logarithmic), 395 which transforms logarithms into composition and 396 


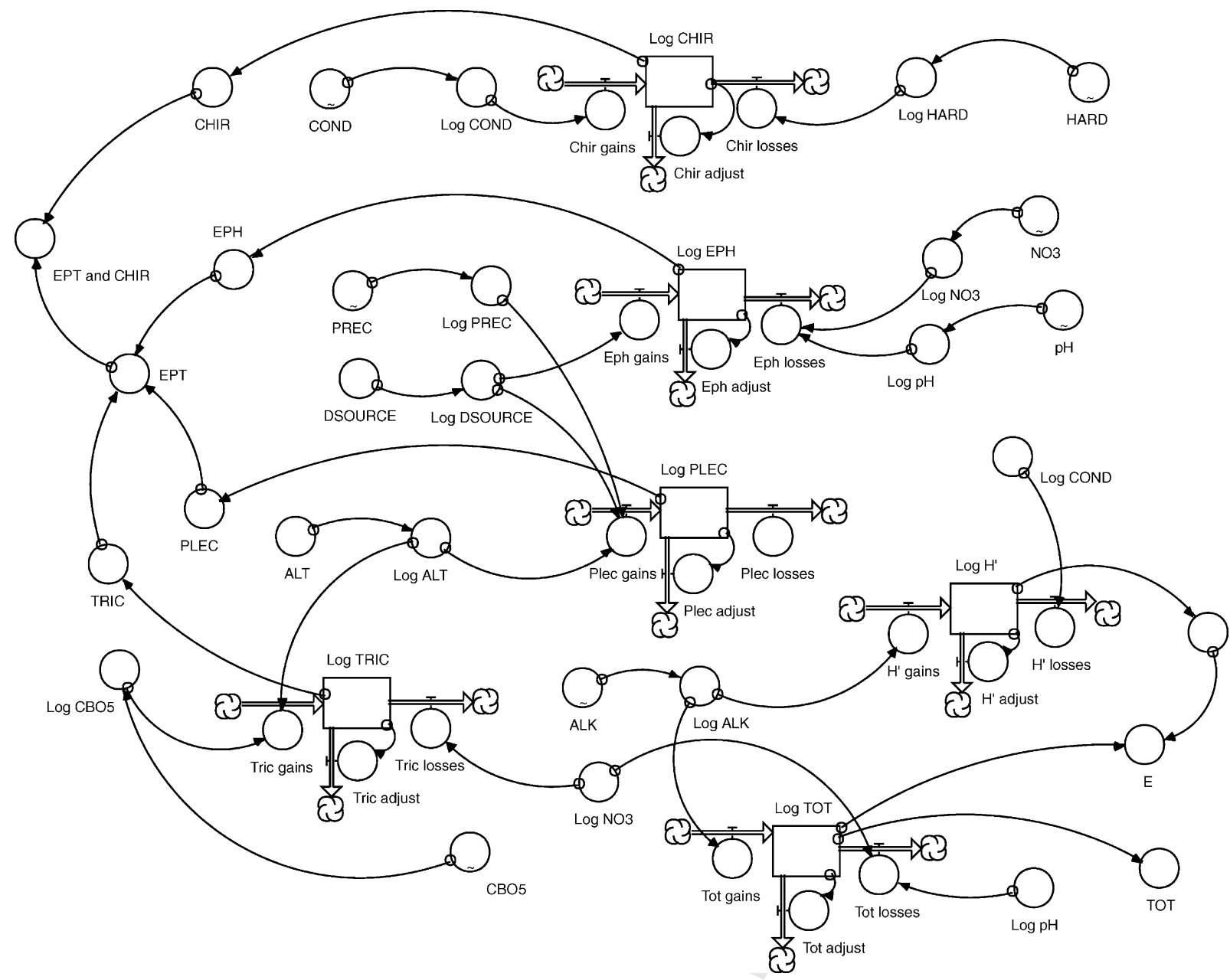

Fig. 2. Conceptual diagram of the model used to predict biological metrics by given environmental variables from the studied watersheds in Northeast Portugal. The specification of all variable codes is expressed in Table 1.

richness expressed in the original measurement units (CHIR, EPH, PLEC, TRIC, TOT, and $\mathrm{H}^{\prime}$ ). The physicochemical variables were logarithm transformed for a compatible integration into the balance of the state variables (Fig. 2 and Table 3, associated variables). This transformation was incorporated because the data required for the state variables balances should use the same units to obtain the significant partial regression coefficients, assumed to be holistic ecological parameters (see Section 2). Therefore, only logarithms of the physicochemical variables are acceptable in the inflows and outflows of the state variables (Fig. 2 and Table 3, Difference and Process equations). Thus, the model is ready to receive and 410 transform real data from the environmental variables 411 and convert logarithmic outputs from state variables 412 simulations into original units. Other variables, re- 413 sulting from simple mathematical operations between 414 the associated variables, such as Pielou's evenness 415 (E), the ratio EPT/(EPT + Chironomidae) (EPT and 416 CHIR), and the EPT metric (EPT), were used to com- 417 plete the output of the model and named composed 418 variables (Table 3, composed variables). Some envi- 419 ronmental values, such as altitude (ALT) and distance 420 from the stream source (DSOURCE), were static, 421 with no variation during the simulated period, and, 422 
Table 3

Mathematical equations used in Stella for the relationships between the composition, richness and tolerance metrics and the environmental physicochemical variables from the studied watersheds

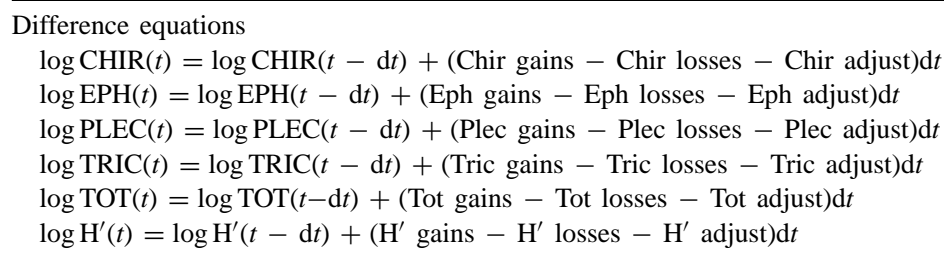

Process equations

(a) Chironomidae

Initial richness of $\log \mathrm{CHIR}=0$

Chir gains $=0.066+0.278 \log$ COND

Chir losses $=0.890 \log$ HARD

Chir adjust $=\log \mathrm{CHIR}$

(b) Ephemeroptera

Initial richness of $\log \mathrm{EPH}=0$

Eph gains $=1.805+0.255 \log$ DSOURCE

Eph losses $=1.718 \log \mathrm{pH}+0.831 \log \mathrm{NO}_{3}$

Eph adjust $=\log \mathrm{EPH}$

(c) Plecoptera

Initial richness of $\log$ PLEC $=0$

Plec gains $=0.145 \log$ PREC $+0.457 \log \mathrm{ALT}+0.256 \log \mathrm{DSOURCE}$

Plec losses $=1.385$

Plec adjust $=\log$ PLEC

(d) Trichoptera

Initial richness of $\log \mathrm{TRIC}=0$

Tric gains $=0.305 \log \mathrm{CBO}_{5}+0.274 \log \mathrm{ALT}$

Tric losses $=0.300+0.822 \log \mathrm{NO}_{3}$

Tric adjust $=\log$ TRIC

(e) Total number of taxa

Initial richness of $\log$ TOT $=0$

Tot gains $=2.548+1.492 \log$ ALK

Tot losses $=1.576 \log \mathrm{pH}+0.961 \log \mathrm{NO}_{3}$

Tot adjust $=\log$ TOT

(f) Shannon-Wiener index

Initial richness of $\log \mathrm{H}^{\prime}=0$

$\mathrm{H}^{\prime}$ gains $=2.548+1.492 \log$ ALK

$\mathrm{H}^{\prime} \operatorname{losses}=1.576 \log \mathrm{pH}+0.961 \log \mathrm{NO}_{3}$

$\mathrm{H}^{\prime}$ adjust $=\log \mathrm{H}^{\prime}$

Associated variables

$\mathrm{CHIR}=10^{\wedge}(\log \mathrm{CHIR})-1$

$\mathrm{EPH}=10^{\wedge}(\log \mathrm{EPH})-1$

PLEC $=10^{\wedge}(\log$ PLEC $)-1$

TRIC $=10^{\wedge}(\log$ TRIC $)-1$

TOT $=10^{\wedge}(\log$ TOT $)-1$

$\mathrm{H}^{\prime}=10^{\wedge}\left(\log \mathrm{H}^{\prime}\right)-1$

$\log \mathrm{ALK}=\log _{10}(\mathrm{ALK}+1)$

$\log \mathrm{ALT}=\log _{10}(\mathrm{ALT}+1)$

$\log \mathrm{BOD}_{5}=\log _{10}\left(\mathrm{BOD}_{5}+1\right)$

$\log \mathrm{COND}=\log _{10}(\mathrm{COND}+1)$

$\log$ DSOURCE $=\log _{10}($ DSOURCE +1$)$

$\log$ HARD $=\log _{10}($ HARD +1$)$

$\log \mathrm{NO}_{3}=\log _{10}\left(\mathrm{NO}_{3}+1\right)$

$\log \mathrm{O}_{2}=\log _{10}\left(\mathrm{O}_{2}+1\right)$ 
Table 3 (Continued)

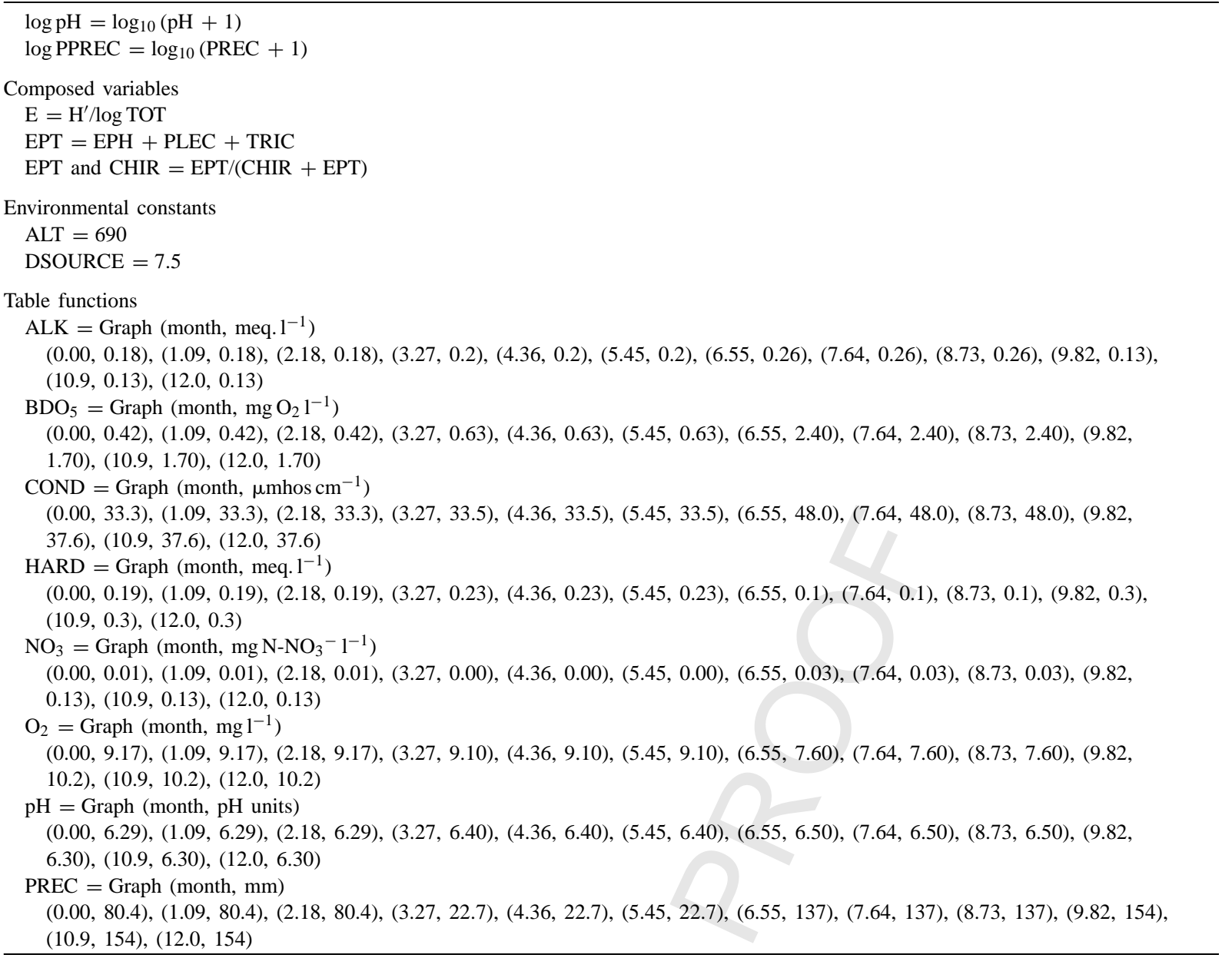

As an example, the environmental data of the sampling station P1 was used. The specification of all variable codes is expressed in Table 1 .

therefore, were introduced as environmental constants (Table 3, Environmental constants).

\subsection{Model simulations}

The temporal unit chosen was the month, because it represents the average ecological variations that occur in lotic systems throughout one or several years. The Euler's integration method was used. For precipitation values, we considered the data from a typical year that would correspond to the averages calculated over a period of 30 years (1961-1990). In this work, all the performed simulations have a total length of 12 months, beginning in the spring, coinciding with the first sampling campaign carried out by Cortes (1992).
For the majority of the relevant metrics adopted, 436 the model successfully predicts the behaviour of the 437 biological metrics under the influence of independent 438 environmental variables from the Pinhão watershed 439 sampling stations (P1, P2, P3 and P4) (Table 4). With 440 the exception of P3, all the simulations were statisti- 441 cally validated by the regression analysis (Model II) 442 of the remaining sampling stations (Table 4). Fig. 3 il- 443 lustrates the confrontation between simulated and real 444 values for the most revealing metrics under consider- 445 ation (Chironomidae, EPT, number of total taxa, and 446 Shannon-Wiener index). For these metrics, the model 447 simulations accurately predicted the real values for P1, 448 P2 and P4, with generally the same behavioural ten- 449 dencies, but not for P3 (Fig. 3 and Table 4). In fact, 450 
Table 4

Regression analysis (Model II) intercepts and slopes, and the respective 95\% confidence limits (in parenthesis), degrees of freedom (d.f.), coefficient of determination $\left(R^{2}\right)$

\begin{tabular}{|c|c|c|c|c|c|c|}
\hline Metrics & Site & Intercept & Slope & d.f. & $R^{2}$ & $F$ \\
\hline EPH & $\begin{array}{l}\mathrm{P} 1 \\
\mathrm{P} 2 \\
\mathrm{P} 3\end{array}$ & $\begin{array}{l}-0.45(-1.05 ; 0.03) \\
0.06(-1.10 ; 0.88) \\
-0.056(-0.83 ; 0.52)\end{array}$ & $\begin{array}{l}1.21(1.02 ; 1.45) \\
1.17(0.87 ; 1.60) \\
0.86(0.59 ; 1.21)\end{array}$ & $\begin{array}{l}11 \\
11 \\
11\end{array}$ & $\begin{array}{l}0.936 \\
0.831 \\
0.788\end{array}$ & $\begin{array}{c}161.13^{* * *} \\
54.211^{* * *} \\
40.92^{* * *}\end{array}$ \\
\hline PLEC & $\begin{array}{l}\mathrm{P} 1 \\
\mathrm{P} 2 \\
\mathrm{P} 3 \\
\mathrm{P} 4\end{array}$ & $\begin{array}{l}-0.73(-1.24 ;-0.32) \\
-0.029(-0.20 ; 0.13) \\
-2.80(-119.12 ;-0.41) \\
-0.003(-0.31 ; 0.23)\end{array}$ & $\begin{array}{l}1.43(1.20 ; 1.72) \\
0.69(0.57 ; 0.80) \\
3.65(1.73 ; 96.76) \\
1.12(0.82 ; 1.55)\end{array}$ & $\begin{array}{l}11 \\
11 \\
11 \\
11\end{array}$ & $\begin{array}{l}0.933 \\
0.941 \\
0.307 \\
0.819\end{array}$ & $\begin{array}{c}154.27^{* * *} \\
176.56^{* * *} \\
4.86^{*} \\
49.68^{* * *}\end{array}$ \\
\hline TRIC & $\begin{array}{l}\mathrm{P} 1 \\
\mathrm{P} 2 \\
\mathrm{P} 3 \\
\mathrm{P} 4\end{array}$ & $\begin{array}{l}-0.69(-2.67 ; 0.55) \\
-0.25(-2.58 ; 1.02) \\
-1.9(-11.43 ; 0.64) \\
0.36(-0.26 ; 0.85)\end{array}$ & $\begin{array}{l}1.55(1.14 ; 2.21) \\
1.49(1.04 ; 2.41) \\
2.71(1.58 ; 6.94) \\
1.14(-1.41 ; 0.92)\end{array}$ & $\begin{array}{l}11 \\
11 \\
11 \\
11\end{array}$ & $\begin{array}{l}0.810 \\
0.716 \\
0.515 \\
0.907\end{array}$ & $\begin{array}{c}46.77^{* * *} \\
27.77^{* * *} \\
11.69^{* *} \\
107.69^{* * *}\end{array}$ \\
\hline EPT & $\begin{array}{l}\mathrm{P} 1 \\
\mathrm{P} 2 \\
\mathrm{P} 3 \\
\mathrm{P} 4\end{array}$ & $\begin{array}{l}-2.05(-4.43 ;-0.23) \\
0.45(-1.60 ; 2.02) \\
-3.42 \\
-0.11(-1.54 ; 1.01)\end{array}$ & $\begin{array}{l}1.43(1.18 ; 1.75) \\
1.09(0.85 ; 1.39) \\
1.92 \\
1.10(0.89 ; 1.38)\end{array}$ & $\begin{array}{l}11 \\
11 \\
11 \\
11\end{array}$ & $\begin{array}{l}0.920 \\
0.883 \\
0.235 \\
0.901\end{array}$ & $\begin{array}{c}126.36^{* * *} \\
83.41^{* * *} \\
3.37 \text { (n.s.) } \\
99.89^{* * *}\end{array}$ \\
\hline CHIR & $\begin{array}{l}\text { P1 } \\
\text { P2 } \\
\text { P3 } \\
\text { P4 }\end{array}$ & $\begin{array}{l}-0.24(-2.55 ; 0.56) \\
-0.42(-4.74 ; 0.83) \\
-1.04(-7.52 ; 0.44) \\
-0.49(-3.59 ; 0.61)\end{array}$ & $\begin{array}{l}1.76(0.99 ; 3.94) \\
1.45(0.69 ; 4.06) \\
1.39(0.58 ; 4.97) \\
1.16(0.51 ; 2.97)\end{array}$ & $\begin{array}{l}11 \\
11 \\
11 \\
11\end{array}$ & $\begin{array}{l}0.732 \\
0.434 \\
0.370 \\
0.431\end{array}$ & $\begin{array}{c}12.69^{* *} \\
8.44^{*} \\
6.46^{*} \\
8.34^{*}\end{array}$ \\
\hline EPT and CHIR & $\begin{array}{l}\mathrm{P} 1 \\
\mathrm{P} 2 \\
\mathrm{P} 3 \\
\mathrm{P} 4\end{array}$ & $\begin{array}{l}-0.008(-0.09 ; 0.06) \\
0.015(-0.11 ; 0.12) \\
0.014(-0.12 ; 0.13) \\
-0.03(-0.24 ; 0.13)\end{array}$ & $\begin{array}{l}1.12(1.01 ; 1.22) \\
1.05(0.89 ; 1.22) \\
1.09(0.93 ; 1.29) \\
1.12(0.88 ; 1.43)\end{array}$ & $\begin{array}{l}11 \\
11 \\
11 \\
11\end{array}$ & $\begin{array}{l}0.981 \\
0.948 \\
0.944 \\
0.977\end{array}$ & $\begin{array}{l}570.69^{* * *} \\
202.19^{* * *} \\
184.27^{* * *} \\
468.98^{* * *}\end{array}$ \\
\hline TOT & $\begin{array}{l}\mathrm{P} 1 \\
\mathrm{P} 2 \\
\mathrm{P} 3 \\
\mathrm{P} 4\end{array}$ & $\begin{array}{l}-2.44(-8.07 ; 1.81) \\
-0.108(-0.83 ; 0.58) \\
-13.85 \\
-0.89(-4.59 ; 2.04)\end{array}$ & $\begin{array}{l}1.08(0.83 ; 1.40) \\
1.08(1.04 ; 1.13) \\
1.91 \\
0.93(0.73 ; 1.20)\end{array}$ & $\begin{array}{l}11 \\
11 \\
11 \\
11\end{array}$ & $\begin{array}{l}0.868 \\
0.996 \\
0.254 \\
0.878\end{array}$ & $\begin{array}{c}72.49^{* * *} \\
2807.2^{* * *} \\
3.75 \text { (n.s.) } \\
79.05^{* * *}\end{array}$ \\
\hline $\mathrm{H}^{\prime}$ & $\begin{array}{l}\mathrm{P} 1 \\
\mathrm{P} 2 \\
\mathrm{P} 3 \\
\mathrm{P} 4\end{array}$ & $\begin{array}{l}-0.026(-0.17 ; 0.11) \\
-0.19(-0.89 ; 0.27) \\
-0.56(-2.67 ; 0.30) \\
-0.37(-1.45 ; 0.23)\end{array}$ & $\begin{array}{l}1.08(0.98 ; 1.18) \\
1.34(0.99 ; 1.87) \\
1.59(0.93 ; 3.23) \\
1.25(0.79 ; 2.09)\end{array}$ & $\begin{array}{l}11 \\
11 \\
11 \\
11\end{array}$ & $\begin{array}{l}0.982 \\
0.820 \\
0.575 \\
0.674\end{array}$ & $\begin{array}{c}595.02^{* * *} \\
50.19^{* * *} \\
14.91^{* *} \\
22.70^{* * *}\end{array}$ \\
\hline $\mathrm{E}$ & $\begin{array}{l}\mathrm{P} 1 \\
\mathrm{P} 2 \\
\mathrm{P} 3 \\
\mathrm{P} 4\end{array}$ & $\begin{array}{l}-0.033(-0.15 ; 0.06) \\
-0.07(-0.35 ; 0.10) \\
-0.089(-0.84 ; 0.19) \\
-0.15(-0.53 ; 0.06)\end{array}$ & $\begin{array}{l}1.18(0.99 ; 1.41) \\
1.32(0.94 ; 1.92) \\
1.32(0.68 ; 2.98) \\
1.35(0.89 ; 2.13)\end{array}$ & $\begin{array}{l}11 \\
11 \\
11 \\
11\end{array}$ & $\begin{array}{l}0.935 \\
0.787 \\
0.499 \\
0.717\end{array}$ & $\begin{array}{c}154.38^{* * *} \\
40.76^{* * *} \\
10.96^{* *} \\
27.94^{* * *}\end{array}$ \\
\hline
\end{tabular}

$F$-values and significance level $\left({ }^{*} P<0.05 ;{ }^{* *} P<0.01 ;{ }^{* * *} P<0.001\right)$, for all the observed vs. expected values of the biological metrics. P1, P2, P3 and P4 represent the four sampling stations of the Pinhão river. (n.s.) not significant. The specification of all variables codes is expressed in Table 1.

the worst performances of the model were always obtained in the sampling station P3, located in an atypical tributary of the Pinhão river (Fig. 1). In P3, the simulated values were frequently underestimated or overestimated (Fig. 3 and Table 4), probably because, in this case, the environmental variables selected do not capture all the relevant variability and heterogene- ity of this particular site. Overall, for the majority of 458 the simulations, the model behaves as expected for the 459 reference situation considered.

After the validation procedures, we tested the 461 model's performance in the face of a new scenario of 462 eutrophization in the sampling station C6, from the 463 Corgo river. Using the same illustrative criteria used 464 

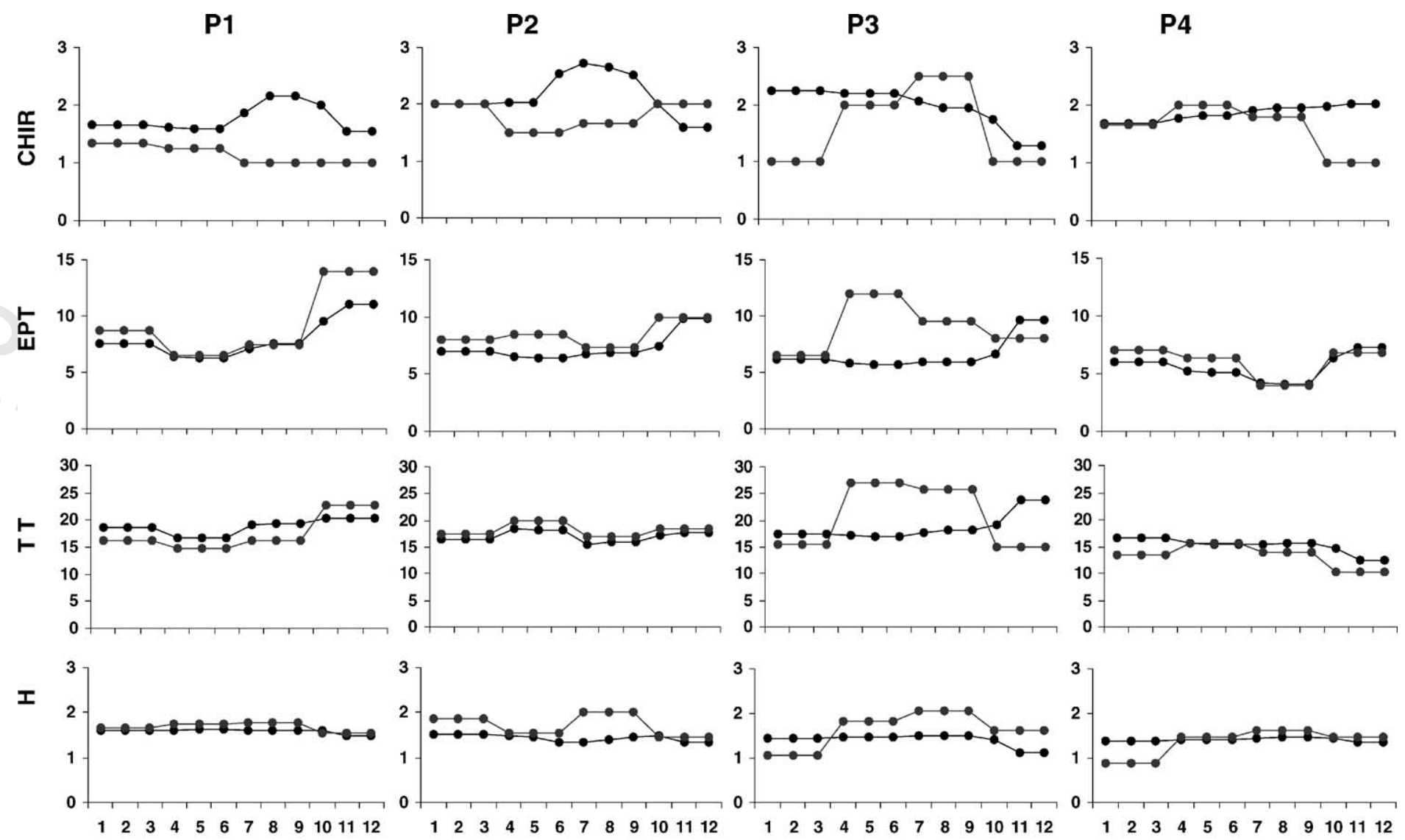

$\mathbf{R}$

Fig. 3. Graphical comparisons between expected (black lines) and observed (grey lines) values of the following biological metrics: Chironomidae (CHIR), EPT, total number of taxa (TOT) and Shannon-Wiener index $\left(\mathrm{H}^{\prime}\right)$. P1, P2, P3 and P4 are the four sampling stations of the Pinhão watershed. 


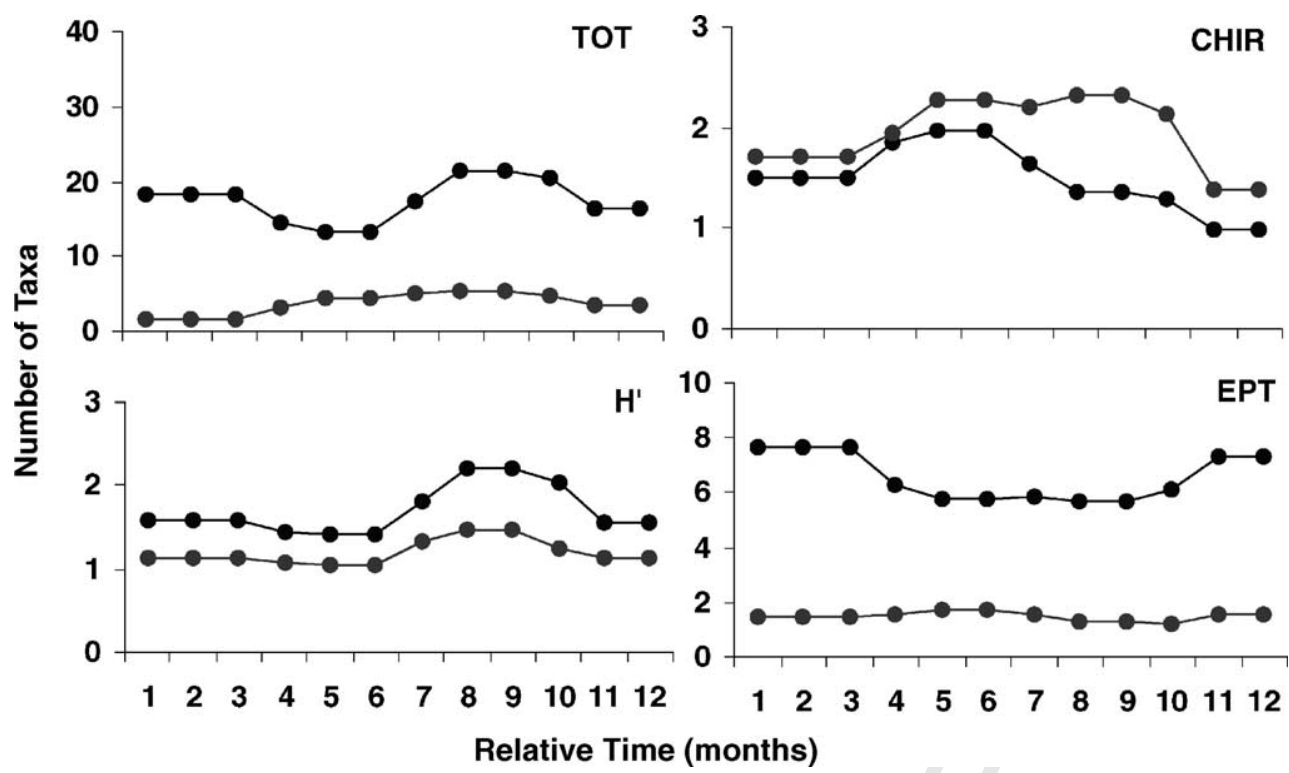

Fig. 4. Model simulations for Chironomidae (CHIR), EPT, total number of taxa (TOT) and Shannon-Wiener index ( $\left.\mathrm{H}^{\prime}\right)$ facing two different scenarios: scenario 1, the reference condition in 1985 (black line) and scenario 2, the perturbed condition in 1995 (grey line), both from the sampling station C6 of the Pinhão watershed.

The stochastic-dynamic methodology developed in this study seems to represent a useful contribution to the assessment of the ecological status of typical run- 487 ning waters, predicting the structure and diversity of 488 key aquatic biological metrics. In fact, the simula- 489 tion results showed that the biological metrics selected 490 as state variables were not indifferent to changes in 491 the environmental conditions, namely when sites rela- 492 tively unaffected by human activities were changed by 493 man-induced disturbances, such as organic pollution. 494 The relevant ecological drifts observed are in agree- 495 ment with other studies that have investigated the bi- 496 ological consequences of aquatic ecosystem changes 497 by these type of anthropogenic impacts on key aquatic 498 communities in general and on macroinvertebrates in 499 particular (e.g. Cortes, 1992; Wright et al., 1995; Fore 500 et al., 1996; Hutchens et al., 1998; DeWalt et al., 1999; 501 Davies et al., 2000; Whiles et al., 2000; Karr and 502 Rossano, 2001; Karr, 2002).

Since the attributes of the macroinvertebrate com- 504 munity structure, such as their respective composi- 505 tion, diversity and abundance are influenced by cer- 506 tain environmental conditions (Karr and Dudley, 1981; 507 Norris et al., 1995; Richards et al., 1993; Roth et al., 508 1996; Townsend et al., 1997a,b; Lounaci et al., 2000; 509 $\mathrm{Li}$ et al., 2001), the developed methodology can be 510 used as a predictive tool for running waters ecologi- 511 
cal assessment. Another goal when developing methods for assessing changes in the ecological integrity of an aquatic ecosystem is the feasibility of application and extent to which the results can be reproduced in other areas (Andreasen et al., 2001). The methodology proposed is expeditious and easily applicable to other aquatic ecosystems affected by environmental changes. The above multivariate statistical analysis used gave robustness to the dynamic interactions, with holistic and ecological relevance included in the model construction and reduces the number of pre-conceptions added to the model. Nevertheless, if we consider that validation is a fundamental process to test the relative accuracy of the model response in relation to its applicability (Rykiel, 1996) then two main questions remain within the present methodology. The first deals with the need for a validation carried out over a wider geographical area (Karr, 2002) and the second requires the use of other key aquatic communities, such as phytoplankton, microphytobenthos, macrophytes, and fish (Barbour et al., 1999).

Despite these considerations, the philosophy of this stochastic-dynamic methodology can be applicable to aquatic ecosystem management and policymaking, providing a useful contribution to define the reference conditions for surface water bodies from the quality elements specified in point 1.1 in Annex $\mathrm{V}$ of the Water Framework Directive 2000/60/EC. This will help not only the public end-users, but also those evaluating environmental quality.

Overall, the main results showed that, as with any complex process in science, it is valid, interesting, and instructive to construct stochastic dynamic models focusing on the interactions between key-components of changing natural ecosystems. This approach may also provide a useful starting point from which to develop more global techniques in the scope of this research area, such the spatial dynamic models and to create expeditious interfaces with Geographical Information Systems, which will make the methodology more instructive and credible to decision-makers and environmental managers (Costanza, 1992, Santos and Cabral, submitted).

\section{Uncited references}

Jørgensen (1999) and Shannon and Wiener (1963).
Acknowledgements

Thanks to Audrey Gerry for the English revision 558 of the manuscript and to Ana Sampaio, from the Bi- 559 ological and Environmental Engineering Department 560 of the University of Trás-os-Montes e Alto Douro, 561 who recorded the physicochemical parameters from 562 the Corgo river in 1994.

\section{References}

Alba-Tercedor, J., Sánchez-Ortega, A., 1998. Un método rápido y simple para avalorar la calidad biológica de las aguas corrientes basado en el Hellawell (1978). Limnetica 4, 51-56.

Andreasen, J.K., O’Neill, R.V., Noss, R., Slosser, N.C., 2001. 568 Considerations for the development of a terrestrial index of 569 ecological integrity. Ecol. Indicators 1, 21-25. 570

Angermeier, P.L., Karr, J.R., 1994. Biological integrity versus 571 biological diversity as policy directives: protecting biotic 572 resources. BioScience 44, 690-697.

Ault, J.S., Luo, J., Smith, S.G., Serafy, J.E., Wang, J.D., Humston, 574 R., Diaz, G.A., 1999. A spatial dynamic multistock production 575 model. Can. J. Fish. Aquat. Sci. 56 (1), 4-25. 576

Barbour, M.T., Gerritsen, J., Snyder, B.D., Stribling, J.B., 1999. 577 Rapid Bioassessment Protocols for Use in Streams and 578 Wadeable Rivers: Periphyton, Benthic Macroinvertebrates and 579 Fish, 2nd ed. U.S. Environmental Protection Agency (EPA), 580 Office of Water, Washington, DC.

Brosse, S., Lek, S., Townsend, C.R., 2001. Abundance, diversity, 582 and structure of freshwater invertebrates and fish communities: 583 an artificial neural network approach. N. Z. J. Mar. Freshwater 584 $35,135-145$.

Cabral, J.A., Marques, J.C., Nielsen, S.N., 2001. Modelling 586 mosquitofish (Gambusia holbrooki) responses to Genapol 587 OXD-080, a non-ionic surfactant, in rice fields. Ecol. Eng. 16, 588 537-544.

Chaloupka, M., 2002. Stochastic simulation modelling of southern 590 Great Barrier Reef green turtle population dynamics. Ecol. 591 Model. 148, 79-109.

Charvet, S., Statzner, B., Useglio-Polatera, P., Dumont, B., 2000. 593 Traits of benthic macroinvertebrates in semi-natural French 594 streams: an initial application to biomonitoring in Europe. 595 Freshwater Biol. 43, 277-296. 596

Cortes, R.M.V., 1992. Seasonal pattern of benthic communities 597 along the longitudinal axis of river systems and the influence 598 of abiotic factors on the spatial structure of those communities. 599 Arch. Hydrobiol. 126, 85-103. 600

Cortes, R.M.V., Oliveira, S.V., Cabral, D.A., Santos, S., Ferreira, 601 T., 2002. Different scales of analysis in classifying streams: 602 from a multimetric towards an integrate system approach. River 603 Res. Appl. 18 (4), 367-382. 604

Costanza, R., 1992. Towards an operational definition of ecosystem 605 health. In: Costanza, R., Norton, B., Haskell, B. (Eds.), 606 Ecosystem Health: New Goals for Environmental Management. 607 Island Press, Washington, DC, pp. 239-256.

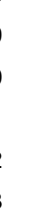


Costanza, R., Voinov, A., 2001. Modelling ecological and economic systems with STELLA: Part III. Ecol. Model. $143(1-2), 1-7$.

Dale, V.H., Beyeler, S.C., 2001. Challenges in the development and use of ecological indicators. Ecol. Indicators 1, 3-10.

Davies, M.N., Norris, R.H., Thomas, M.C., 2000. Prediction and assessment of local stream habitat features using large-scale catchment characteristics. Freshwater Biol. 45, 343-369.

DeWalt, R.E., Webb, D.W., Harris, M.A., 1999. Summer Ephemeroptera, Plecoptera, and Trichoptera (EPT) species richness and community structure in the Lower Illinois river basin of Illinois. The Great Lakes Entomol. 32 (3), 115-132.

Dolèdec, S., Statner, B., Bournaud, M., 1999. Species traits for future biomonitoring across ecoregions: patterns along a humanimpacted river. Freshwater Biol. 42, 737-758.

Fore, L.S., Karr, J.R., Wisseman, R.W., 1996. Assessing invertebrate responses to human activities: evaluating alternative approaches. J. N. Am. Benthol. Soc. 15, 212-213.

Harris, G., 2002. Integrated assessment and modelling: an essential way of doing science. Environ. Model. Softw. 17 (3), 201-207.

Harris, J.H., Silveira, R., 1999. Large-scale assessments of river health using an index of biotic integrity with low-diversity fish communities. Freshwater Biol. 41, 235-252.

Hutchens Jr., J., Chung, K., Wallace, J.B., 1998. Temporal variability of stream macroinvertebrate abundance and biomass following pesticide disturbance. J. N. Am. Benthol. Soc. 17 (4), 518-534.

Jørgensen, S.E., 1994. Models as instruments for combination of ecological theory and environmental practice. Ecol. Model. $75 / 76,5-20$

Jørgensen, S.E., 1999. State-of-the-art of ecological modelling with emphasis on development of structural dynamic models. Ecol. Model. 120, 75-96.

Jørgensen, S.E., 2001. Fundamentals of Ecological Modelling, 3rd ed. Elsevier, Amsterdam, 630 pp.

Jørgensen, S.E., de Bernardi, R., 1997. The application of a model with dynamic structure to simulate the effect of mass fish mortality on zooplankton structure in Lago de Annone. Hidrobiologia 356, 87-96.

Karr, J.R., 1998. Rivers as sentinels: using the biology of rivers to guide landscape management. In: Naimam, R.J., Bilby, R.E. (Eds.), River Ecology and Management-Lessons From the Pacific Coastal Ecoregion, Springer-Verlag, New York, pp. 502-528.

Karr, J.R., 1999. Defining and measuring river health. Freshwater Biol. 41, 221-234.

Karr, J.R., 2002. What from ecology is relevant to design and planning? In: Johnson, B.R. Hill, K. (Eds.), Ecology and Design: Frameworks for Learning. Island Press, Washington, DC, pp. 133-172.

Karr, J.R., Dudley, D.R., 1981. Ecological perspective on water quality goals. Environ. Manage. 5 (1), 55-68.

Karr, J.R., Chu, E.W., 2001. Sustaining living rivers. Hydrobiology 422/423, 1-14.

Karr, J.R., Rossano, E.M., 2001. Applying public health lessons to protect river health. Ecol. Civil Eng. 4, 3-18.
Kay, W.R., Smith, M.J., Pinder, A.M., McRae, J.M., Davies, J.A., 665 Halse, S.A., 1999. Patterns of distribution of macroinvertebrate 666 families in rivers of north-western Australia. Freshwater Biol. 667 41, 299-316.

Kimberling, DN , Karr, J.R., Fore, L., 2001. Measuring human 669 disturbance using terrestrial invertebrates in shrub-step of 670 eastern Washington (USA). Ecol. Indicators 1, 63-81. 671

Kurtz, J.C., Jackson, L.E., William, S.F., 2001. Strategies for 672 evaluating indicators based on guidelines from the environ- 673 mental protection agency's office of research and development. 674 Ecol. Indicators 1, 49-60.

Lenat, D.R., 1998. Water quality assessment of streams using a 676 qualitative collection method for benthic macroinvertebrates. J. 677 N. Am. Benthol. Soc. 7, 222-233. 678

Li, J., Herlihy, A., Gerth, W., Kaufmann, P., Gregory, S., Urquhart, 679 S., Larsen, D.P., 2001. Variability in stream macroinvertebrates 680 at multiple spatial scales. Freshwater Biol. 46, 87-97.

Lounaci, A. Brosse, S., Thomas, A., Lek, S., 2000. Abundance, 682 diversity and community structure of macroinvertebrates in an 683 Algerian stream: the Sébaou wadi. Ann. Limnol. 36, 123-133. 684

Mackay, R.J., 1992. Colonization by lotic macroinvertebrates: a 685 review of process and patterns. Can. J. Fish. Aquat. Sci. 49, 686 617-628. fication of macroinvertebrate communities across drainage 689 basins in Victoria, Australia: consequences of sampling on a 690 broad spatial scale for predictive modelling. Freshwater Biol. 691 41, 253-268.

Maxted, J.R., Barbour, M.T., Gerritsen, J., Primrose, N., Silvia, A., 693 Penrose, D., Renfrow, R., 2000. Assessment framework for mid 694 Atlantic coastal plain streams using benthic macroinvertebrates. 695 J. N. Am. Benthol. Soc. 19 (1), 128-144.

Mitsch, W.J., Jørgensen, S.E., 1989. Introduction to ecological 697 engineering. In: Mitsch, W.J., Jørgensen, S.E. (Eds.), Ecological 698 Engineering. Wiley, New York, pp. 3-12. 699

Moss, D., Wrigth, J.F., Furse, M.T., Clarke, R.T., 1999. A 700 comparison of alternative techniques for prediction of the fauna 701 of running-water sites in Great Britain. Freshwater Biol. 41, 702 167-181.

Norris, R.H., Hart, B.T., Finlayson, M., Norris, K.R., 1995. Use 704 of the biota to access water quality. Aust. J. Ecol. 20, 1-27. 705

Oberdorf, T., Pont, D., Hugheny, B., Chessel, D., 2001. A 706 probabilistic model characterizing fish assemblages of French 707 rivers: a framework for environmental assessment. Freshwater 708 Biol. 46, 399-415.

Parsons, M., Norris, R.H., 1996. The effect of habitat specific 710 sampling on biological assessment of water quality using a 711 predictive model. Freshwater Biol. 36, 419-434. 712

Pauw, N.E., Vanhooren, G., 1983. Method for biologic quality 713 assessment of watercourses in Belgium. Hidrobiologia 100, 714 $153-168$.

Rabeni, C.F. 2000. Evaluating physical habitat integrity in relation 716 to the biological potential of streams. Hydrobiologia 422/423, 717 245-256.

Ribaudo, M.O., Hoag, D.L., Smith, M.E., Heimlich, R., 2001. 719 Environmental indexes and the politics of the conservation 720 reserve program. Ecol. Indicators 1, 11-20. 721 66 6

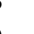

1

3

75

7

979

0

1

2

4

87

8

9

691

92

4

695

695
696
697

9

700

701
702
703

05

08

09

1

13

15
720 
Richards, C., Host, G.E., Arthur, J.W., 1993. Identification of predominant environmental factors structuring stream macroinvertebrate communities within a large agricultural catchment. Freshwater Biol. 29, 285-294.

Roth, N.E., Allan, J.D., Erickson, D.E., 1996. Landscape influences on stream biotic integrity assay at multiple spatial scales. Landscape Ecol. 11, 141-156.

Rykiel Jr., E.D., 1996. Testing ecological models: the meaning of validation. Ecol. Model. 90, 229-244.

Sampaio, A.C.R., 1995. Evaluation of a Mini-Hidric Impact in a Lotic Ecosystem: In a Particular Case of Terragido in Corgo River. MSc. Thesis University of Trás-os-Montes e Alto Douro, Vila Real.

Seager, J., 1999. Perspectives and limitations of indicators in water management. J. Aquat. Ecosyst. Health 21, 44-48.

Shannon, C.E., Wiener, W., 1963. The Mathematical Theory of Communication. University of Illionois Press, Urbana, $117 \mathrm{pp}$.

Smith, M.J., Kay, W.R., Edward, D.H.D., Papas, P.J., Richardson, St. J., Simpson, J.C., Pinder, A.M., Cale, D.J., Horwitz, P.H.J., Davis, J.A., Yung, F.H., Norris, R.H., Halse, S.A., 1999. AusRivAS: using macroinvertebrates to assess ecological condition of rivers in Western Australia. Freshwater Biol. 41, 269-282.

Sokal, R.R., Rohlf, F.J., 1995. Biometry, 3rd ed. W.H. Freeman and Company, New York.

Thorne, R.St.J., Williams, W.P., 1997. The response of benthic invertebrates to pollution in developing countries: a multimetric system of bioassessment. Freshwater Biol. 37, 671-686.

Townsend, C.R., Riley, R.H., 1999. Assessment of river health: accounting for perturbation pathways in physical and ecological space. Freshwater Biol. 41, 393-405.

Townsend, C.R., Dolédec, S., Scarsbrook, M.R., 1997a. Species traits in relation to temporal and spatial heterogeneity in streams: a test of habitat template theory. Freshwater Biol. 37, 367-387.

Townsend, C.R., Arbuckle, C.J., Crrowl, T.A., Scarsbrook, M.R., 1997b. The relationship between land use and physicochemistry, food resources and macroinvertebrate communities in tributaries 758 of the Taieri River, New Zealand: a hierarchically scaled 759 approach. Freshwater Biol. 37, 177-191. 760

Turak, E., Flack, L.K., Norris, R.H., Simpson, J., Waddell, 761 N., 1999. Assessment of river condition at a large spatial 762 scale using predictive models. Freshwater Biol. 41, 283- 763 298.

Voinov, A., Voinov, H., Constanza, R., 2001. Surface water flow 765 in landscape models. 2. Patuxent watershed case study. Ecol. 766 $\begin{array}{ll}\text { Model. 119, 211-230. } & 767\end{array}$

Wallace, J.B., 1990. Recovery of lotic macroinvertebrate commu- 768 nities from disturbance. Environ. Manage. 14, 605-620. 769

Whiles, M.R., Brock, B.L., Franzen, A.C., Dinsmore, S.C., 2000. 770 Stream invertebrate communities, water quality, and land-use 771 patterns in an agricultural drainage basin of Northeastern 772 Nebraska, USA. Environ. Manage. 26 (5), 563-576. 773

Wright, J.F., 1995. Development and use of a system for predicting 774 the macroinvertebrate fauna in flowing waters. Aust. J. Ecol. 775 20, 181-197.

Wright, J.F., Armitage, P.D., Furse, M.T., Moss, D., 1989. 777 Prediction of invertebrate communities using stream measure- 778 ments. Regul. Rivers: Res. Manage. 4, 147-155. 779

Wright, J.F., Blackburn, J.H., Westlake, D.F., Furse, M.T., 780 Armitage, P.D., 1992. Anticipating the consequences of river 781 management for the conservation of macroinvertebrates. In: 782 Boon, P.J., Calow, P. Petts, G.E. (Eds.), River Conservation and 783 Management. Wiley, New York, pp. 137-149. 784

Wright, I.A., Chessman, B.C., Fairweather, P.G., Benson, L.J., 785 1995. Measuring the impact of sewage effluent on the macro- 786 invertebrate community of an upland stream: the effect of 787 different levels of taxonomic resolution and quantification. Aust. 788 J. Ecol. 20, 142-149. 789

Yount, J.D., Niemi, G.J., 1990. Recovery of lotic macroinvertebrate 790 communities and ecosystems from disturbance: a narrative 791 review of case studies. Environ. Manage. 14, 547-569. 792

Zar, J.H., 1996. Biostatistical Analysis, 3rd ed. Prentice-Hall 793 International Inc., Englewood Cliffs, NJ. 1

\section{4}

8

